\title{
Teaching Vocabulary to Turkish EFL Learners via the Cartoons of Three English Classics ${ }^{1}$
}

\author{
Nalan KIZILTAN \\ Ondokuz Mayıs Üniversitesi \\ kiziltan@omu.edu.tr \\ Zülal AYAR ${ }^{2}$ \\ Ankara Üniversitesi \\ ayarz@ankara.edu.tr
}

Gönderilme Tarihi: 31/12/2019

Kabul Tarihi: 28/03/2020

Yayınlanma Tarihi: 31/03/2020

DOI: $10.30855 /$ gjes.2020.06.01.007

\begin{tabular}{l} 
Article Info \\
\hline Key Words: \\
Vocabulary \\
teaching, \\
Cartoons, \\
Gender, \\
Age, \\
Achievement
\end{tabular}

\section{ABSTRACT}

The purpose of that study is to investigate the implementation of vocabulary teaching through cartoons on students who have read texts in the format of comic strips and the ones reading without the support of any illustrations. This paper also aims to reveal the effects of students' age and gender during vocabulary teaching process. Cartoon extracts of three classics from English literature, Great Expectations by Charles Dickens, Romeo \& Juliet by William Shakespeare, and Treasure Island by Robert Louis Stevenson have been utilized for the experiment. On the one hand, 47 Turkish students taking English courses in Research and Application Centre at a state university in Turkey were in the experimental group, and they were exposed to cartoons. On the other hand, randomly drawn 20 took part in the control group who read stories in plain text formats. According to the results of this quasiexperimental research, a significant difference could not be detected between two groups. Nevertheless, the experimental group was more successful in vocabulary achievement rates than the control group. Moreover, the results indicated the fact that female students were more successful than the males in word knowledge, and 20-29 year-old students were distinguished to be better than the other age groups.

${ }^{1}$ This article was produced from a master's thesis prepared by Zülal Ayar under the supervision of Prof. Dr. Nalan Kiziltan.

${ }^{2}$ Corresponder Author

Kiziltan, N., \& Ayar, Z. (2020). Teaching vocabulary to Turkish EFL learners via the cartoons of three English classics. Gazi Eğitim Bilimleri Dergisi, 6(1), 111-128. DOI: https://dx.doi.org/110.30855/gjes.2020.06.01.007

Dergi Web Sayfasi: http://dergipark.gov.tr/gebd 


\section{Yabancı Dil Olarak İngilizce Öğrenen Türk Öğrencilere Üç İngiliz Klasiğinin Karikatürüyle Kelime Öğretimi}

\begin{tabular}{ll}
\hline \hline Makale Bilgileri & ÖZET \\
Anahtar & Bu çalışma, karikatürleri hem resimli hem de görsel ögelerle \\
Kelimeler: & zenginleştirilmemiş formatta okuyan iki grup öğrencinin kelime \\
Karikatürler, & öğrenim başarısını incelemeyi hedeflemektedir. Ayrıca, kelime öğretimi \\
Cinsiyet, & sürecinde öğrencilerin yaş ve cinsiyetlerinin başarıları üzerindeki etkisi \\
Yaş, & de çalışmanın kapsamındadır. Charles Dickens'ın Great Expectations, \\
Başarı oranı & William Shakespeare'in Romeo \& Juliet ve Robert Louis Stevenson'ın \\
& Treasure Island adlı eserlerinden alınan hikayeler uygulama esnasında \\
& kullanılmıştır. Bir devlet üniversitesinin uygulama ve araştırma \\
& merkezinde İngilizce dersi alan 47 Türk öğrenci deney grubunda yer \\
& almış ve metinleri karikatürler ile okumuştur. Rastlantısal seçilen 20 \\
& öğrenci ise hikayeleri karikatürsüz ve görsel destek olmadan \\
& okuduklarından kontrol grubunu oluşturmuştur. Bu yarı deneysel \\
& çalışmanın sonuçları her iki grup arasında anlamlı bir faklılık \\
& olmadığını göstermektedir. Ancak, deney grubu kelime öğreniminde \\
& daha yüksek bir başarı elde etmiştir. Dahası, kız öğrencilerin kelime \\
& bilgisi bakımından erkeklere göre daha başarılı olduğu, 20-29 yaş \\
& aralı̆̆ındaki öğrencilerin diğer yaş gruplarından daha iyi performans \\
& gösterdikleri kaydedilmiştir. \\
\hline &
\end{tabular}

\section{INTRODUCTION}

Though teaching four basic skills seems to be the matter of hot debate in foreign language context, students are also required to gain relevant vocabulary knowledge according to their levels by virtue of the fact that words are lynchpins of teaching all the skills (Nation, 1994; 1999). Another reason why word items are accepted as the backbone of language studies originates from the fact that vocabulary is among the best markers of spoken skill, and it raises linguistic awareness as well as word recognition in turn. As a result, vocabulary teaching has been taken into account in the course of time by different scholars. For instance, Crystal (2003) defines vocabulary as the Everest of language because a person eager to communicate in a certain language has to master its vocabulary for the first time.

In and of itself, Lessard-Clouston (2012, p.2) specifies that vocabulary does deal with words. Yet vocabulary is much more than just single words. Therefore, vocabulary can be defined as "the words of a language, including single items and phrases or chunks of several words which covey a particular meaning the way individual words do". Vocabulary addresses single lexical items - words with specific meaning(s) - but it also includes lexical phrases or chunks, such as Good morning and Nice to meet you. Furthermore, by considering the severity of vocabulary information in language settings, Takač (2008) affirms that the learners should also decide on 
which lexical items to learn with the help of their selective attention in parallel to their needs and then determine how, where and how often to use them. However, while concentrating on the word knowledge, the learners first of all get to know the aspects and constituents of vocabulary in general sense. Therefore, the definition of 'knowing a word' ought to be well-known. Lightbown and Spada (2013, p.64) clarify its items step by step:

- Grasping the general meaning in a familiar context,

- Providing a definition or a translation equivalent,

- Providing appropriate word associations,

- Identifying its component parts or etymology,

- Using the word to complete a sentence or to create a new sentence,

- Using it metaphorically,

- Understanding a joke that uses homonyms.

Similar to Lightbown and Spada (2013), Nation (2001) and Thornbury (2000) correlate word knowledge with identification of its form, meaning and use for both receptive and productive skills. Form covers some parts of a word that can be decomposed and analysed, which explains how units and words are comprised. Meaning is the connection that people automatically form having heard the vocabulary. Finally, use implies the application of this vocabulary with grammatical aspects of the language besides collocations and connotations. Likewise, Grabe (2009) opts for describing this term comprehensively with the claim that it incorporates a range of units, such as register, parts of speech, pronunciation, orthography and morphology.

Due to the fact that word knowledge requires competencies in quite a few aspects of the language, teaching vocabulary has been studied a lot in EFL context (Altınok, 2000; Atay \& Kurt, 2006; Sonbul \& Schmitt, 2009; Şen \& Kuleli, 2015; Shen, 2003). The influences of interactive games, authentic activities, technology (Birinci, 2014), storytelling and drama have sparked a lot of interest among researchers (Alabi, 2015; Apdy \& Asrifan, 2018; Bensalem, 2018; Demircioğlu, 2010; Özer \& Koçoğlu, 2017; Tavakoli \& Gerami, 2012). Likewise, Liu (2004) and Hudson (1982) centred upon the liaison between students' failure to comprehend the text and their reading preferences. However, deeming the advantage of adopted techniques by Pikulski and Templeton (2004) in vocabulary teaching and learning continuum, then operationalizing cartoons as the instructional instruments would also seem to avail and foster learning motivation among students. Thus, initially this concept, cartoons, is to be delineated elaborately within foreign language education framework. 
Scientifically, illustrations or visuals include drawings, pictures, comic strips, cartoons, and photographs, any kind of images, graphics, charts, maps or video films. Thereby, illustration can be entitled as an umbrella term covering any visual materials. As to picture, it will be used as the synonym of an image or a drawing. Yet, cartoon differs from all of these definitions in a way. McCloud (1993) clarifies this characteristic in that a string of juxtaposed images have been gathered successively and intentionally in order to transmit a message to the reader. As such, cartoon not only represents pictures about what is narrated in the text like other visuals in the list, but it gives place to a reading text as well.

Bedenbaugh (2008) and Genç (2004) in the same vein underscore teaching vocabulary and the pivots in selection of vocabulary to be oriented to the learners through cartoons. They stress the necessity of principles in the defining what word items to teach. Bedenbaugh (2008) and Zimmerman (2008) also declare these principles as frequency, opportunism, coverage, range, salience, and availability, a word learning burden, brevity and regularity of form. Those tenets describe how cartoons outdo all the other visuals displaying pictures as well as enriching them with vocabulary by taking consideration of many pedagogical norms just to increase productivity of the learners by smoothing the way for them.

Even though cartoons are categorized under the heading of illustrations or visuals and pictures, they have three different types in their own right. These varied versions of cartoons in the sense of educational goals ought to be explained thoroughly. Cartoons could be editorial which is the one that characterizes something striking in the news. Because they express cartoonists' views, sometimes they might be uttered political cartoons, too. They include caricatures with exaggerated drawings reflecting a clear outlook about the occasion. Another is called as panel comics or gag cartoons. They cover only one panel, a frame where the image is supported with a punch line. They show a group of people than merely one person, such as greeting cards. The other cartoon type is comic strips, which include portrayal and speech bubbles in sequence panels. Out of all cartoon types, comic strips will be the most effective vehicle both for teachers and learners since in language learning, the language itself and any adopted materials have to be quite clear. Bearing this in mind and espousing the ideas of aforementioned scholars, the following research questions have been addressed to design the current study:

1. Are there any statistical differences between the achievement scores of the learners who have been exposed to cartoons and those of the learners who have been exposed to the texts without cartoons?

2. Is there a statistical difference in vocabulary achievement scores between the male and the female learners in the experimental group? 
3. Is there a statistical difference in vocabulary achievement scores of the experimental group at the ages of $10-19,20-29$ and 30 or more?

\section{METHOD}

\section{Participants and Setting}

This study was implemented on sixty-seven Turkish learners of English language at intermediate level to investigate the impacts of cartoons in vocabulary teaching process in the research and application centre of a state university in Ankara, Turkey in 2015. Twenty-eight female, nineteen males and in total forty-seven participants took part in the experimental group, while the control group consisted of twenty subjects, eleven females and nine males. In addition, the age range was discerned to vary from fifteen to fourty-five years in both groups.

\section{Data Collection}

Initially, three well-known English classic cartoons Great Expectations by Charles Dickens, Romeo \& Juliet by William Shakespeare and Treasure Island by Robert Louis Stevenson were selected. Afterwards, they were classified into three main categories: coloured, black and white (colourless) texts and cartoons without comic strips. The researchers divided intermediate classes into two as the control and the experimental groups; while coloured and black and white cartoon versions of classics (comic strips) were assigned to the experimental group, texts without illustrations were given to the control group. In each lesson, the students in both groups were appointed with a text from the same classic. The reason behind delivering the texts separately instead of the whole classics was to teach target words by using relevant activities as had already been underlined by Cary (2004) and Wenborn (2008). Firstly, three texts out of Treasure Island were extracted to be handled by the population. For Romeo $\mathcal{E}$ Juliet, four texts were assigned in succession, and then three texts from Great Expectations were selected for randomly drawn students in two groups.

In order to explain how the instruments were employed during the experiment, two developed lesson plan models were in need to be examined rigorously. The researchers planned the first lesson plan to make students become knowledgeable about the target words chosen from Treasure Island within a meaningful context. In warm-up, the students were posed some basic questions related with reading, their concern about the cartoons and any other illustrated materials in dialogues. After reawakening their background knowledge, the teacher asked students to read the texts and identify the unknown words. In the second round, they started to read cartoons again to be able to discover the meanings of those words on their own with the help of contexts. In presentation, assuming that they had already learned the leading characters in the texts, the teacher introduced 'wh ... questions', by this way she would reveal to what extent 
students could comprehend and recognize the texts. Respecting their responses, she touched upon word formation process to encourage them to apprehend how to compete with unfamiliar phrases. In what follows, the students fulfilled a guided information gap test in parallel to the words they had just acquired to reinforce their intakes. In production, the teacher wanted students to examine the unknown words they could not solve the meanings out for the last time. Thereafter, students shared unfamiliar words and hence collaborated with others in class. In the final phase, the teacher wrote some relevant prompts on the board and stimulated students to use them all while making up a story particularly by drawing on those recently acquired words before they were assigned with writing homework to be submitted in the next lesson.

Adhering to the framework of second lesson plan, identical to the first one, the students were intended to be familiar with the target words in context. Still, this time they were exposed to two classics Great Expectations and Romeo \& Juliet simultaneously. The reason was that the number of word units identified to be tricky or confusing were not as many as in Treasure Island. In this lesson, warm-up activity was composed of questions related to the text so as to enhance prior knowledge activation through brainstorming and with the influence of cartoons. Upon reading the texts from Great Expectations, the students had a discussion with their partners about the illustrations in the story only then were they supposed to interpret the story considering the factual information. Having completed reading both texts, students underlined unknown words once more and tried to guess the meanings. In order to familiarize students with Romeo $\mathcal{E}$ Juliet, the teacher would also embody a dubious cartoon from the story to solve the hidden meanings and messages within group works. Following her explanations, she also aimed to reinforce the sense of lexical units via making students distinguish the roles of word families. In production, the problematic words were again talked over in pair-works, and besides that, students were reoriented to write a short story by using the given prompts to extend word retention process in minds before vocabulary tests.

Two weeks after the implementation, two vocabulary tests made up of 25 questions each were administered to both groups to check their vocabulary retention skills. The first vocabulary test was about Treasure Island, whereas the second one included the words from the classics Romeo $\mathcal{E}$ Juliet and Great Expectations. As aforementioned, Treasure Island was assessed on an individual base owing to a vast number of words exposed to students in comparison to Great Expectations and Romeo \& Juliet. Nevertheless, two vocabulary tests were designed by taking account the same basic objective which was to unveil the students' overall achievement in terms of vocabulary use upon learning the target words through three English classic cartoons. The vocabulary tests consisted of four parts, which were guided information gap test, multiple choice test, and matching and information gap test. To begin with, in the first part of guided information gap test, 
the students were asked 25 words from classic cartoons. However, they were expected to answer only nine questions and use nine words out of 25 by choosing them from the box. The utterances with no same usage in classics were deliberately covered to check students' comprehension. Still, their ability to use of vocabulary in the light of its meaning and style, functions and formation of grammar points could only be checked in the name of memory skills. In the next section, there were five multiple choice questions with the inclusion of the target words. Following this, matching six pictures with six-word items was addressed to the students. Holding the same principle in the first part and not allowing them to memorize or recite the texts, no identical illustrations were directly copied from the classics. In the last part of the vocabulary test, the students tried to fill the blanks as much as they could remember the classics. The essential reason behind such a kind of neat design was to find out how competent the students were in their comprehension skills after the administration of same exercises chiming in with the lesson plans.

\section{Data Analysis}

In regard to the statistical result, t-test was used for vocabulary achievement scores of both groups, and one-way Anova test was run to indicate gender-specific vocabulary achievements. The data were analysed by Statistical Package for the Social Sciences (SPSS) 21 for Windows packaged software. Accordingly, the cronbach alpha of the vocabulary test was $a=0.899 \mathrm{implying}$ the fact that it was approved to be valid and reliable.

\section{FINDINGS}

Bearing in mind the aim of detecting the effects of cartoons in vocabulary learning process of English language students at intermediate level, the data collection process was performed, and as a result the findings were discussed in accordance with three research questions respectively.

\section{The Results According to Vocabulary Test Scores}

Table 1 indicates that the experimental group's mean in vocabulary test scores was 49,19, whereas it was 44,40 in the control group. Furthermore, vocabulary achievement scores of both experimental and control groups from two vocabulary tests were searched $t(65)=1.092$.

Table 1.

Vocabulary Test Results of the Groups

\begin{tabular}{llcccccc}
\hline & \multicolumn{1}{c}{ Group } & $\mathbf{N}$ & $\overline{\mathbf{X}}$ & $\mathbf{S}$ & $\mathbf{s d}$ & $\mathbf{t}$ & $\mathbf{p}$ \\
\hline \multirow{3}{*}{ Vocabulary Test Score } & Experimental Group & 47 & 49.19 & 17.55 & 65 & 1.092 & .279 \\
& Control Group & 20 & 44.40 & 13.30 & & & \\
\hline
\end{tabular}

Even though there was no significant difference between mean scores of the groups $(p=.279>.05)$, the experimental group seemed to be more successful than the control group. 
Nevertheless, when the experimental group's overall achievement in vocabulary test was considered, it cannot be claimed to be so propitious. This is because they could not even reach the half of total score over 100. It would give point to the emphasis on the lack of vocabulary competence of the students.

In order to pinpoint the achievements of the students from each classic, the achievement scores of the experimental and control groups from three classics were shown in Table 2 separately.

Table 2.

Achievement Scores of Both Groups According to the Parts in the Vocabulary Test

\begin{tabular}{|c|c|c|c|c|c|c|}
\hline Group & Parts of the Vocabulary Test & $\mathbf{N}$ & Min. & Max. & $\overline{\mathbf{X}}$ & $\mathbf{S}$ \\
\hline \multirow{8}{*}{ 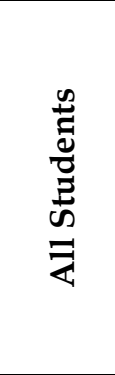 } & TI Guided Information Gap Test & 66 & 0 & 16 & 5.60 & 5.13 \\
\hline & TI Multiple Choice Test & 66 & 0 & 10 & 6.09 & 3.29 \\
\hline & TI Matching Test & 66 & 2 & 12 & 10.09 & 2.72 \\
\hline & TI Information Gap Test & 66 & 0 & 2 & 0.03 & 0.02 \\
\hline & RJ \&GE Guided Information Gap Test & 67 & 0 & 18 & 8.65 & 5.24 \\
\hline & RJ \&GE Multiple Choice Test & 67 & 0 & 10 & 6.38 & 8.79 \\
\hline & RJ \&GE Matching Test & 67 & 0 & 12 & 10.65 & 16.45 \\
\hline & RJ \&GE Information Gap Test & 67 & 0 & 10 & 0.56 & 1.86 \\
\hline \multirow{8}{*}{ 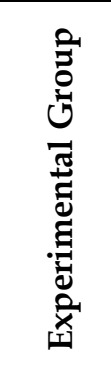 } & TI Guided Information Gap Test & 46 & 0 & 16 & 6.08 & 5.43 \\
\hline & TI Multiple Choice Test & 46 & 0 & 10 & 6.13 & 3.51 \\
\hline & TI Matching Test & 46 & 6 & 12 & 10.13 & 2.57 \\
\hline & TI Information Gap Test & 46 & 0 & 2 & 0.04 & 0.29 \\
\hline & RJ \&GE Guided Information Gap Test & 47 & 0 & 18 & 9.23 & 5.26 \\
\hline & RJ \&GE Multiple Choice Test & 47 & 0 & 10 & 6.68 & 3.15 \\
\hline & RJ \&GE Matching Test & 47 & 0 & 12 & 10.80 & 2.52 \\
\hline & RJ \&GE Information Gap Test & 47 & 0 & 8 & 0.55 & 1.70 \\
\hline \multirow{8}{*}{ 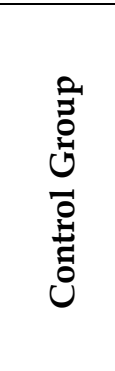 } & TI Guided Information Gap Test & 20 & 0 & 16 & 4.50 & 4.29 \\
\hline & TI Multiple Choice Test & 20 & 0 & 10 & 6.00 & 2.82 \\
\hline & TI Matching Test & 20 & 2 & 12 & 10.00 & 3.11 \\
\hline & TI Information Gap Test & 20 & 0 & 0 & 0.00 & 0.00 \\
\hline & RJ \&GE Guided Information Gap Test & 20 & 0 & 16 & 7.30 & 5.07 \\
\hline & RJ \&GE Multiple Choice Test & 20 & 0 & 10 & 5.70 & 3.51 \\
\hline & RJ \&GE Matching Test & 20 & 0 & 12 & 10.30 & 3.13 \\
\hline & RJ \&GE Information Gap Test & 20 & 0 & 10 & 0.60 & 2.25 \\
\hline
\end{tabular}

(TI: Treasure Island, RJ: Romeo \& Juliet, GE: Great Expectations)

When compared with the results of control group, the experimental group appeared to be more successful in using vocabulary items in Romeo $\mathcal{E}$ Juliet and Great Expectations with the average score of 10,80. Moreover, the findings of two groups indicated that the lowest score was detected in Treasure Island. After vocabulary achievement scores of experimental groups were scrutinized via matching exercise, these students were found to be more successful in Great Expectations and Romeo \& Juliet, yet higher underachievement rates were mostly observed in Treasure Island by means of information gap test. This result may also originate from the fact reported by Hashemzadeh (2012) that filling the blanks or matching activities were one step 
ahead than the others and thus more appropriate for students, since the students in the experimental group must have learned the vocabulary items through visuals in matching parts, which would directly correspond to the semantic components of the vocabulary items as well.

Table 3.

Correct and Wrong Answers to the Target Vocabulary Items

\begin{tabular}{|c|c|c|c|c|c|c|c|}
\hline Vocabulary Items & Correct & Wrong & $\%$ & Vocabulary Items & Correct & Wrong & $\%$ \\
\hline Jewel & 65 & 2 & 97.0 & Outskirts & 35 & 32 & 52.2 \\
\hline Mug & 65 & 1 & 98.5 & Brewery & 33 & 34 & 49.3 \\
\hline Drunkenness & 64 & 2 & 97.0 & Revenge & 32 & 35 & 47.8 \\
\hline Bride & 63 & 4 & 94.0 & Excuse & 29 & 37 & 43.9 \\
\hline Herbs & 61 & 6 & 91.0 & Funeral & 27 & 39 & 40.9 \\
\hline Potion & 61 & 6 & 91.0 & Tomb & 25 & 42 & 37.3 \\
\hline Gambling & 57 & 9 & 86.4 & Adopt & 25 & 42 & 37.3 \\
\hline Enemy & 54 & 13 & 80.6 & Desperate & 23 & 43 & 34.8 \\
\hline Stain & 53 & 14 & 79.1 & Tired & 23 & 43 & 34.8 \\
\hline Dull & 50 & 17 & 74.6 & Circumstance & 21 & 45 & 31.8 \\
\hline Sailing & 50 & 16 & 75.8 & Hasty & 16 & 51 & 23.9 \\
\hline Deck & 49 & 17 & 74.2 & Skipper & 15 & 51 & 22.7 \\
\hline Wicked & 49 & 17 & 74.2 & Cove & 13 & 53 & 19.7 \\
\hline Stare & 49 & 17 & 74.2 & Conspiracy & 11 & 55 & 16.7 \\
\hline Anxious & 47 & 19 & 71.2 & Gale & 9 & 57 & 13.6 \\
\hline Convince & 46 & 21 & 68.7 & Ruin & 6 & 61 & 9.0 \\
\hline Dawn & 45 & 22 & 67.2 & Heal & 5 & 62 & 7.5 \\
\hline Stuff & 45 & 21 & 68.2 & Forgive & 4 & 63 & 6.0 \\
\hline Evil & 42 & 25 & 62.7 & Wound & 3 & 64 & 4.5 \\
\hline Cure & 40 & 27 & 59.7 & Misuse & 1 & 66 & 1.5 \\
\hline Passage & 39 & 28 & 58.2 & Blew & 1 & 65 & 1.5 \\
\hline Pity & 38 & 29 & 56.7 & Unintentionally & 0 & 66 & 0.0 \\
\hline Forge & 38 & 29 & 56.7 & Hearty & 0 & 66 & 0.0 \\
\hline Barrel & 38 & 28 & 57.6 & Rough & 0 & 66 & 0.0 \\
\hline Sundown & 35 & 31 & 53.0 & Haunted & 0 & 66 & 0.0 \\
\hline
\end{tabular}

In the above table, the students' correct and wrong responses to the vocabulary related questions after teaching performance were given. Most of the students appeared to know the words 'jewel, mug, drunkenness' and 'bride'. The possible reason behind their success was that the students were asked to match the vocabulary items with the help of pictures, namely visual support must have accelerated their memory use. Additionally, concerning to the list of meaning types of Leech (1974), the words 'bride' and 'drunkenness' were used with their conceptual meanings. As to 'mug', the word must have been known in advance by the students because of its being a cultural figure. On the other hand, though the suggestions of Bedenbaugh (2008) and Genç (2004) were considered before identifying three classics in the experiment, 'unintentionally, hearty, rough' and 'haunted' in Treasure Island could not be responded in the correct forms by the population. It may be because of the language level of the text which might be a little bit above their linguistic competence. Moreover, the type of the test must be difficult for the students who were asked to fill in the blanks. Firstly, the word 'hearty', carrying the sense of cheerful and 
wholesome to define food and the word 'haunt', having the explanation of 'a place for socializing', 'visiting as a spirit' or 'having an effect' might have puzzled the students in connotative meanings. When the word 'rough' was checked in Treasure Island, it came out with a thematic meaning (.... looks like we have some rough sailing ahead..). Bearing the other expressions of the word 'bumpy, rude, simple, stormy' and 'approximate', rough may have been put in reflected and collocative meaning types as well. Nonetheless, specific to Treasure Island, the students in the experimental group must have understood merely half of the vocabulary items in the test as is seen in Table 4 .

Table 4.

The Experimental Group's Achievement Scores from Treasure Island

\begin{tabular}{lccc}
\hline Vocabulary Items & Correct & Wrong & Achievement \% \\
\hline Drunkenness & 46 & 0 & 100 \\
Mug & 45 & 1 & 97.8 \\
Gambling & 39 & 7 & 84.8 \\
Deck & 35 & 11 & 76.1 \\
Sailing & 34 & 12 & 73.9 \\
Wicked & 34 & 12 & 73.9 \\
Stare & 34 & 12 & 73.9 \\
Stuff & 32 & 14 & 69.6 \\
Anxious & 32 & 14 & 69.6 \\
Barrel & 27 & 19 & 58.7 \\
Sundown & 24 & 22 & 52.2 \\
Excuse & 23 & 23 & 50.0 \\
Funeral & 20 & 26 & 43.5 \\
Tired & 18 & 28 & 39.1 \\
Desperate & 17 & 29 & 37.0 \\
Circumstance & 16 & 30 & 34.8 \\
Skipper & 11 & 35 & 23.9 \\
Cove & 10 & 36 & 21.7 \\
Conspiracy & 9 & 37 & 19.6 \\
Gale & 8 & 38 & 17.4 \\
Blew & 1 & 45 & 2.2 \\
Haunted & 0 & 46 & 0.0 \\
Unintentionally & 0 & 46 & 0.0 \\
Hearty & 0 & 46 & 0.0 \\
Rough & 0 & 46 & 0.0 \\
\hline
\end{tabular}

When the word 'drunkenness' which was correctly answered by all the students was checked out how to be used in cartoons, the picture about this word made it clear that everything was quite clear for the students to predict its meaning in cartoon. Similar to 'drunkenness', the word 'deck' was really well-depicted, which probably made the students lead to select it out of other alternatives in the test. On the other hand, the students' success in vocabulary test was recorded to get a decrease while they were working on the words 'rough, haunted, 
unintentionally, hearty'. In order to learn the underlying reasons, the illustrations from the text required to be examined. Initially, the word 'rough' might not have been interpreted because of the lack of visual supplementation. At first sight, the dark clouds were clearly visible; however, particularly in black and white cartoons they may not have guided students to understand its contextual meaning. A similar reason behind the failure of the following word 'haunted' would also be stated after its usage in context was analyzed. It was when the leading character, Jim, was talking about how villain the captain was and how he captured his dreams with his monstrous look. The readers cannot have observed any visual clues in the cartoon to associate the words 'haunted' and 'the bad guy' and to comprehend its sense, thereby they must have mainly chosen wrong options in the vocabulary test. This reason was also unambiguous in that students may have learned these words before, and when reinforced with pictures in cartoons, they seemed to able to derive their meanings. It might also derive from the students' failure in recognizing synonymy of lad, to keep an eye open, seafaring, haunted as were indicated by $\mathrm{Hu}$ (2001), Leech (1974), and Fromkin, Rodman and Hyams (2003).

Table 5.

Experimental Students' Achievement Scores from Great Expactations and Romeo \& Juliet

\begin{tabular}{lccc}
\hline Vocabulary & Correct & Wrong & Achievement \% \\
\hline Jewel & 46 & 1 & 97.9 \\
Potion & 45 & 2 & 95.7 \\
Bride & 45 & 2 & 95.7 \\
Herbs & 42 & 5 & 89.4 \\
Dull & 38 & 9 & 80.9 \\
Stain & 38 & 9 & 80.9 \\
Enemy & 38 & 9 & 80.9 \\
Cure & 32 & 15 & 68.1 \\
Dawn & 32 & 15 & 68.1 \\
Evil & 31 & 16 & 66.0 \\
Convince & 31 & 16 & 66.0 \\
Passage & 30 & 17 & 63.8 \\
Forge & 29 & 18 & 61.7 \\
Brewery & 27 & 20 & 57.4 \\
Outskirts & 27 & 20 & 57.4 \\
Revenge & 25 & 22 & 53.2 \\
Pity & 24 & 23 & 51.1 \\
Adopt & 19 & 28 & 40.4 \\
Tomb & 16 & 31 & 34.0 \\
Hasty & 13 & 34 & 27.7 \\
Ruin & 4 & 43 & 8.5 \\
Heal & 4 & 43 & 8.5 \\
Forgive & 3 & 44 & 6.4 \\
Wound & 2 & 45 & 4.3 \\
Misuse & 0 & 47 & 0.0 \\
\hline
\end{tabular}

After examining Treasure Island, the other texts retrieved from Romeo \& Juliet and Great Expectations were also required to be discussed in detail. Initially, 'bride', which was among the 
highest scored vocabulary, was enriched with illustrations throughout the story. Its comprehension was furthered with vivid explanations and pictures displaying the lady in a wedding dress. Furthermore, 'herbs' can also be classified as the most successfully responded word relying on the vocabulary test results above. Viewed cognitively, in this cartoon strip from Great Expectations, the character 'Friar Laurence' expressed 'herbs' in plain terms to be grasped by the students within a particular context.

Having analyzed the highly scored words, the researchers probed into all vocabulary items and indicated which ones were not replied correctly by the majority of students. To begin, the words labelled as problematic by the experimental group were 'forge, wound' and 'misuse' as is seen in table 5 in the vocabulary test. In order to find out the basic motives behind this deficiency, the uses of these words were to be resolved within the text. With regard to that, students appeared to have been deprived of any kinds of connected figures or expressions and visual enrichments while reading and guessing the meanings of these words from the texts. In parallel, students in the experimental group must have used their critical thinking process, predictions, reasoning and thinking far less while reading the cartoons at that point.

In order to highlight the potential effects of cartoons in teaching vocabulary, students in the experimental group were also assessed in terms of their familiarity to these words by checking out their scores after the teaching performance as follows:

Table 6.

The Number of Words and Students' Achievement Scores according to the Test

\begin{tabular}{|c|c|c|c|c|c|c|}
\hline Group & $\begin{array}{l}\text { The number of the words and students' } \\
\text { achievement scores according to the test }\end{array}$ & $\mathbf{N}$ & Min. & Max. & $\overline{\mathbf{X}}$ & $\mathbf{S}$ \\
\hline \multirow{7}{*}{ 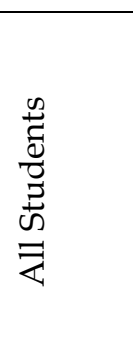 } & RJ \& GE Unknown Words & 67 & 0 & 16 & 4.58 & 4.45 \\
\hline & RJ \& GE Learned Words & 67 & 0 & 9 & 1.81 & 2.32 \\
\hline & RJ \& GE Score & 67 & 8 & 44 & 26.27 & 9.28 \\
\hline & TI Unknown Words & 66 & 0 & 15 & 4.18 & 4.36 \\
\hline & TI Learned Words & 66 & 0 & 8 & 1.53 & 2.05 \\
\hline & TI Score & 66 & 6 & 38 & 21.82 & 8.79 \\
\hline & Total Mark & 67 & 16 & 80 & 47.76 & 16.45 \\
\hline \multirow{7}{*}{ 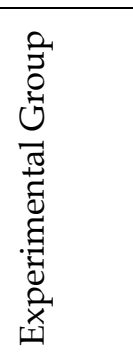 } & RJ \& GE Unknown Words & 47 & 0 & 16 & 5.11 & 4.76 \\
\hline & RJ \& GE Learned Words & 47 & 0 & 9 & 2.04 & 2.59 \\
\hline & RJ \& GE Score & 47 & 8 & 44 & 27.28 & 9.57 \\
\hline & TI Unknown Words & 47 & 0 & 15 & 4.57 & 4.43 \\
\hline & TI Learned Words & 46 & 0 & 8 & 1.74 & 2.25 \\
\hline & TI Score & 46 & 6 & 38 & 22.39 & 9.33 \\
\hline & Total Mark & 47 & 16 & 80 & 49.19 & 17.55 \\
\hline
\end{tabular}


Table 6.

Continues

\begin{tabular}{|c|c|c|c|c|c|c|}
\hline \multirow{6}{*}{ 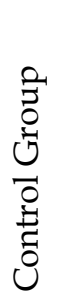 } & RJ \& GE Unknown Words & 20 & 0 & 12 & 3.35 & 3.43 \\
\hline & RJ \& GE Learned Words & 20 & 0 & 5 & 1.25 & 1.41 \\
\hline & RJ \& GE Score & 20 & 12 & 40 & 23.90 & 8.29 \\
\hline & TI Unknown Words & 20 & 0 & 14 & 3.30 & 4.16 \\
\hline & TI Learned Words & 20 & 0 & 4 & 1.05 & 1.43 \\
\hline & TI Score & 20 & 10 & 38 & 20.50 & 7.45 \\
\hline & Total Mark & 20 & 24 & 72 & 44.40 & 13.30 \\
\hline
\end{tabular}

(TI: Treasure Island, RJ: Romeo \& Juliet, GE: Great Expectations)

In the above given table, depending on the mean scores, the students in the experimental group could attain 2.04 mean out of 25, whereas the control group could get only 1,25 out of 25 . This means that $10 \%$ success rate was detected in experimental group, while it was solely $5 \%$ in the control group. Though the accomplishment rates between two groups were reported to be inequal, and this difference could not be proved to be significant, it would be impossible to claim that control group was fortunate enough to construct target vocabulary with informationprocessing triggered via cartoons. To sum up, by considering the general result upon the analyses of all text types in the vocabulary test, what can be easily asserted is that experimental group was more adventegous than control group according to their score.

Regarding anoher rationale of examining students' success and perceiving their potential troubles in reading, we stated that the leading difficulty may have also arisen from ethics, which were open to interpretations particularly in Treasure Island. Besides that, students might have been acknowledged about the story in advance and thus foresee the final. This is because its author Stevenson opted for back to front narration, which might have created amotivation among the students. As to the other possible motive, we noticed that majorly former texts instead of ensuing chapters were extracted to be inserted in the research, which may have hindered them to understand how the story evolved unlike in Romeo \& Juliet and Great Expectations. When all these grounds were combined with the stylistic narration of Stevenson, the low performance of students in Treasure Island would not be tough to estimate indeed.

\section{The Results According to Gender}

As illuminated by Schmitt (2000), correct vocabulary use incorporates a wide variety of factors, such as gender and age. Bearing in mind the fact that they might also constitute a threat before learning new words, a deep analysis about them was required to be adopted herein. Even though in language teaching and learning, the females were accepted to be one step ahead of the males (Özyllmaz, 2012) on the whole, the current study also touched upon this issue and try to substantiate it within the scope. 
Table 7.

Achievement Scores of the Experimental Group According to Gender

\begin{tabular}{lllccccc}
\hline & Gender & $\mathbf{N}$ & $\overline{\mathbf{X}}$ & $\mathbf{S}$ & $\mathbf{s d}$ & $\mathbf{t}$ & $\mathbf{p}$ \\
\hline \multirow{2}{*}{ Vocabulary Test Score } & Female & 28 & 51.79 & 15.35 & 45 & 1.237 & .223 \\
& Male & 19 & 45.37 & 20.21 & & & \\
\hline
\end{tabular}

In Table 7, females in the experimental group had an average of 51.79 in vocabulary test, while the mean among male subjects was 45,37 . That is, no significant difference could be detected accordingly $(\mathrm{t}(45)=1.237, \mathrm{p}=.223>.05)$. Although this result was correlated with Piske, Mackay and Flege (2001), it was incompetable with $\mathrm{Gu}$ (2002) who revealed that the female had an apparent mastery over the male group in language learning.

\section{The Results According to Age}

Referring to the last research question, we have created the following table to indicate vocabulary test results of experimental group depending on their ages.

Table 8.

Achievement Scores of the Experimental Group According to Age

\begin{tabular}{ccccccc}
\hline & Age & $\mathbf{N}$ & $\overline{\mathbf{X}}$ & $\mathbf{S}$ & $\mathbf{F}$ & $\mathbf{p}$ \\
\hline \multirow{3}{*}{ Vocabulary Test Score } & $\mathbf{1 0 - 1 9}$ & 21 & 47.14 & 14.37 & 1.429 & .250 \\
& $\mathbf{2 0 - 2 9}$ & 20 & 53.70 & 20.44 & & \\
& $\mathbf{3 0 +}$ & 6 & 41.33 & 15.78 & & \\
\hline
\end{tabular}

As is seen in table 8 , similar to the first two findings, no significant differences were detected among students in vocabulary test scores according to their age range $(F(2-44)=1.429$, $p=.250>.05$ ). However, 20-29 year-old students were distinguished to be better than the other two age groups in terms of exploiting cartoons in learning word items.

The first declaration underlying this result might be introduced as the students aged 10 to 19 may have regarded cartoons totally instrumental orientations, such as a tool instead of integrative orientations or combination of these two. Accordingly, this could hinder the real language acquisition. Another reason for 30 or more aged group can be related with the fact that they might not have held reading texts as real tools letting the students achieve vocabulary learning. In the same manner, because the lessons were lectured in different sessions, their practice on target words may be less than other participants at different ages. Likewise, Nation (1999), Johnson and Engelbeck (1989) mentioned the importance of repetition that no matter how many mnemonic equipments could be handled during learning, forgetting would directly start after the lessons. In accordance with this ill effect of repetition, 30 or more aged English students might have experienced difficulty in all retention skills of recalling, retrieval, and recognition like a domino effect. 


\section{CONCLUSION}

The aim of this research was in general sense to reveal the impacts of cartoons on vocabulary learning depending on age and gender variables of the learners. The research questions of the study were about the role of the cartoons in teaching vocabulary, the differences between the achievement scores of the students in experimental and control groups considering their gender and age groups.

To find answers to three research questions, a quasi-experimental research design was employed. Hence, in order to assess the efficiency of the cartoons in vocabulary teaching, the students in experimental group were exposed to classic cartoons Romeo \& Juliet by William Shakespeare, Great Expectations by Charles Dickens, and Treasure Island by Robert Louis Stevenson, either in colored or black and white formats, whereas the control group read plain texts without any visuals. Finally, all the subjects were given vocabulary test to check their retention skills about the target vocabulary. The findings displayed that there was no significant influence of cartoons on improving students' vocabulary competence. The experimental group managed to reach the mean score of 49.19 in the achievement test, while the control group had the mean achievement score of 44.40. Even though this was not a significant difference, experimental group could obtain a little more success in their vocabulary learning performance the at the level of significance of .279. In more concrete words, similar to the claims of Pikulski and Templeton (2004), these results would prove that the cartoons seemed to be beneficial for the students in the experimental group to comprehend the vocabulary items in reading texts in general sense though.

Respecting age range of the students, the most successful group was subjects at the age of 20-29, then 10-19 and lastly 30 or more. When compared with the other two age groups, 30 or more aged students were less successful in vocabulary achievement tests. This result must derive from the critical age in learning. In terms of gender in regards to achievement scores in vocabulary test, the females were more successful (51.79) than males (45.37) in spite of the insignificant difference at the level of .223. In short, the results of the study were found to be consistent with Liu (2004) and Hudson (1982) in that visuals and cartoons can be effective in students' language learning studies.

\section{REFERENCES}

Alabi, A. M. (2015). Teaching vocabulary through poetry in an EFL classroom. International Journal of New Trends in Arts, Sports \& Science Education, 4(4), 22-30.

Altınok, Ş. İ. (2000). Teaching vocabulary using collocations versus using definitions in EFL classes. Master's Thesis. Retrieved from: http://repository.bilkent.edu.tr/handle/11693/18208 
Apdy, A. P. R., \& Asrifan, A. (2018). The Chinese mime game in teaching vocabulary on EFL classroom. Proceeding of the 65th TEFLIN International Conference, Universitas Negeri Makassar, Indonesia 12-14 July, 65 (1), 28-40.

Atay, D., \& Kurt, G. (2006). Elementary school EFL learners' vocabulary learning: The effects of post-reading activities. The Canadian Modern Language Review, 63(2), 255-273.

Bedenbaugh, L. (2008). Graphic novels in my classroom? University of Central Florida. Retrieved from: http://flare.ucf.edu/FLaRE_Presentations.htm

Bensalem, E. (2018). The impact of whatsapp on EFL students' vocabulary learning. Arab World English Journal (AWEJ), 9(1), 23-38.

Birinci, F. G. (2014). The effectiveness of visual materials in teaching vocabulary to deaf students of EFL.

Master's Thesis. Retrieved from: http://www.openaccess.hacettepe.edu.tr:8080/xmlui/handle/11655/1924

Cary, S. (2004). Going graphic: Comics at work in the multilingual classroom. Portsmouth: Heinemann. Crystal, D. (2003). The Cambridge encyclopedia of the English language. Cambridge: CUP. Print.

Demircioğlu, S. (2010). Teaching English vocabulary to young learners via drama. Procedia, 2, 439443.

Fromkin, V., Rodman, R., \& Hyams, N. (2003). An introduction to language (Seventh Ed.). Wadsworth-Thomson.

Genç, B. (2004). New trends in teaching and learning vocabulary. Çukurova University Journal of Social Sciences, 13(2), 117-126.

Grabe, W. (2009). Reading a second language moving from theory to practice. New York: Cambridge University Press.

Gu, Y. (2002). Gender, academic major, and vocabulary learning strategies of Chinese EFL learners. RELC Journal, 33(1), 35-54.

Harrar, A. (2009). Treasure Island. Kalyani Navyug Media. CampFire.

Hashemzadeh, M. (2012). The effect of exercise types on EFL learners' vocabulary retention. Theory and Practice in Language Studies. 2(8), 1716-1727.

Hu, Z. (2001). Linguistics. A course book. Second Edition. Beijing University Press.

Hudson, T. (1982). The effects of induced schemata on the "short circuit" in L2 reading: Nondecoding factors in L2 reading performance. Language Learning, 32, 132.

Johnson, J., \& Engelbeck, G. (1989). Modes survey results. SIGCHI Bulletin, 20(4), 38-50.

Lessard-Clouston, M. (2012). Vocabulary learning and teaching: Pedagogy, research, and resources. 9th Christians in English Language Teaching (CELT 2012) Conference Teaching with Excellence Strand.

Leech, G. (1974). Semantics: The study of meaning. Penguin UK.

Lightbown, P., \& Spada, N. (2013). How languages are learned. Oxford University Press. 
Liu, J. (2004). Effects of comic strips on L2 learners' reading comprehension. TESOL Quarterly, $38(2), 225-243$.

McCloud, S. (1993). Understanding comics: The invisible art. Northampton, MA: Kitchen Sink Press.

McDonald, J. (2009). Romeo \& Juliet. The graphic novel. Quick test. Classical comics.

Nation, I. S. P. (1994). New ways in teaching vocabulary. Alexandria, VA.: TESOL.

Nation, I. S. P. (1999). Learning vocabulary in another language. Victoria University of Wellington: English Language Institute Occasional Publication.

Nation, I. S. P. (2001). Learning vocabulary in another language. Cambridge University Press.

Özer, Y. E., \& Koçoğlu, Z. (2017). The use of quizlet flashcard software and its effects on vocabulary learning. Ankara Universitesi, TÖMER Dil Dergisi, 168(1), 61-81.

Özyılmaz, Ö. (2012). An investigation into ELT students' academic achievement and their use of language learning strategies across gender groups. Master's Thesis. North Cyprus.

Pikulski, J., \& Templeton, S. (2004). Teaching and developing vocabulary: Key to long-term reading success. Houghton Mifflin Company.

Piske, T., Mackay, R. I., \& Flege, J. (2001). Factors affecting degree of foreign accent in an L2: A review. Journal of Phonetics. 29(1), 191-215.

Shen, W. (2003). Current trends of vocabulary teaching and learning strategies for EFL settings. Feng Chia Journal of Humanities and Social Sciences, 7, 187-224.

Schmitt, N. (2000). Vocabulary in language teaching. Cambridge University Press.

Sonbul, S., \& Schmitt, N. (2009). Direct teaching of vocabulary after reading: Is it worth the effort? ELT Journal, 64(3), 253-260.

Şen, Y., \& Kuleli, M. (2015). The effect of vocabulary size and vocabulary depth on reading in EFL context. Procedia - Social and Behavioral Sciences, 199, 555-562.

Takač, V. P. (2008). Vocabulary learning strategies and foreign language education. Multilingual matters. British Library Cataloguing in Publication Data.

Tavakoli, M., \& Gerami, E. (2012). The effect of keyword and pictorial methods on EFL learners' vocabulary learning and retention. Porta Linguarum, 19, 299-316.

Thornbury, S. (2000). How to teach vocabulary. Harlow: Person Longman Education.

Viney, B. (2010). Great expectations. The ELT graphic novel. Classical comics.

Wenborn, K. (2008). Teaching resource pack Romeo \& Juliet. Classical comics study guide. Classical Comics Ltd. First UK Edition.

Zimmerman, B. C. (2008). Word knowledge. Oxford: Oxford University Press. 